\title{
Public fight vs air pollution: is the monitoring system a first step for air quality management in the town of Bitola
}

\author{
Beti Angelevskaa ${ }^{a}$, Vaska Atanasova ${ }^{a}$, Aleksandar Markoski ${ }^{b}$ \\ a Faculty of Technical Sciences, Bitola, N. Macedonia \\ ${ }^{b}$ Faculty of Information and Communication Technology, Bitola, N. Macedonia
}

\begin{tabular}{|c|c|}
\hline ARTICLE INFO & ABSTRACT \\
\hline $\begin{array}{l}\text { DOI: } 10.31075 / \text { PIS.65.04.04 } \\
\text { Professional paper } \\
\text { Received:10/12/2019 } \\
\text { Accepted:20/12/2019 }\end{array}$ & \multirow{5}{*}{$\begin{array}{l}\text { Air quality remains one of the most pressing problems in urban areas. Providing } \\
\text { information about air pollution and finding out its spatial distribution through } \\
\text { monitoring network is a crucial starting point in the planning process of } \\
\text { measures for air quality control and improvement. Hence, monitoring is an } \\
\text { indispensable component of air quality management and its first activity. But, } \\
\text { despite the significant deterioration of air quality in the town of Bitola, there is a } \\
\text { lack of monitoring network and systematic measurements. Considering the } \\
\text { importance of monitoring and its absence in the town of Bitola, this analysis } \\
\text { gives an overview of the current air pollution problem and public initiative and } \\
\text { determination for changes. Most importantly, elaborated recommendations for } \\
\text { introduction of monitoring network in the town are presented. }\end{array}$} \\
\hline $\begin{array}{l}\text { Selected paper from 7th } \\
\text { International conference } \\
\text { "TOWARDS A HUMANE CITY" }\end{array}$ & \\
\hline $\begin{array}{l}\text { Corresponding author: } \\
\text { beti.angelevska@tfb.uklo.edu.mk }\end{array}$ & \\
\hline Keywords: & \\
\hline $\begin{array}{l}\text { Monitoring } \\
\text { Air quality } \\
\text { Bitola town }\end{array}$ & \\
\hline
\end{tabular}

\section{INTRODUCTION}

Air pollution is one of the most important environmental concerns, particularly in urban areas. To protect humans and the environment from damage by air pollution, it is of the utmost importance to measure the levels of air pollutants [1].

Air quality monitoring provides the basic information for air pollution levels, and appoints the polluters of bigger concern. The continuous monitoring is necessary for dealing with air quality problems, in wider extent and higher certainty [2].

For effective approach to air pollution management, it is of particular importance to diagnose the pollution problem of urban air, to assess the impacts from pollution sources and to identify available and sustainable solutions [2]. The first step always is determining the seriousness and nature of air pollution problem. This can be perform by air quality monitoring network, which unfortunately, for the town of Bitola is missing.

Having in mind the significance of air quality management for air pollution control and reduction, and the lack of monitoring as a starting point to handle air pollution problem in the town of Bitola, public revolt and displeasure is understandable and justifiable.
As well as public insistence not to reconcile with the unacceptable air quality situation, this paper is trying through analysis of the current inconsistencies in air quality maintenance, to tackle the problem in its core and to indicate a way out. As already mention, monitoring data have potential to optimize air quality management. Hence, recommendations for creation and placement of monitoring network as a starting activity for building of system for air quality management are elaborated.

\section{THE AIR POLLUTION PROBLEM IN BITOLA}

\subsection{Main air polluters}

As in most of other urban areas, air pollution in Bitola town is caused by industry and urban transport as main air polluters.

Industrial polluters are represented by the biggest thermo-plant in Macedonia for production of electricity, located near the town (10 km distance). It produces almost $80 \%$ of the electricity needed for the country, using high quantities of coal as a single energy source. In comparison with pollution amounts from this plant, other much smaller and not very numerous industrial factories in Bitola, mainly using oil, have insignificant contribution to air pollution [4]. 
The economic situation in the town of Bitola and in the country in general defines the average age of the urban vehicle fleet. Therefore, the biggest part of the vehicles - around $47 \%$ (approximately 10.000 vehicles) are older, ranging from 14-20 years and above 20 years [5]. Being frequently used on everyday level, these vehicles realize significant part of passenger kilometers in the town with higher exhaust emissions at the same time.

Households could be counted as a significant pollution source in winter, considering that town doesn't have central heating. Usually, their first choice for heating are cheaper energy sources, such as wood or coal. Unfortunately, aren't any statistical data for this.

Nevertheless, all these facts clearly highlight the seriousness of the actual air pollution problem in the Bitola town.

\subsection{Current monitoring situation}

In practice, placement of the monitoring network in a wider urban area most often is very expensive and with high working and maintenance cost [2]. Not all cities have monitoring network that covers the whole area and/or mobile monitoring equipment.

Bitola is such a town without monitoring network. There are only two monitoring stations: Bitola 1 is located in the town's periphery, at $13 \mathrm{~km}$ distance from the previously mentioned plant; Bitola 2 is in the town's centre, in public organization's courtyard. Bitola 2 is very often out of order. Both stations measure: $\mathrm{O}_{3}$, $\mathrm{NO}_{2}, \mathrm{SO}_{2}, \mathrm{CO}$ и $\mathrm{PM}_{10}$. The stations aren't mutually connected. Results from Bitola 1 are used in the reports of Ministry of environment, health organizations, NGO and others.

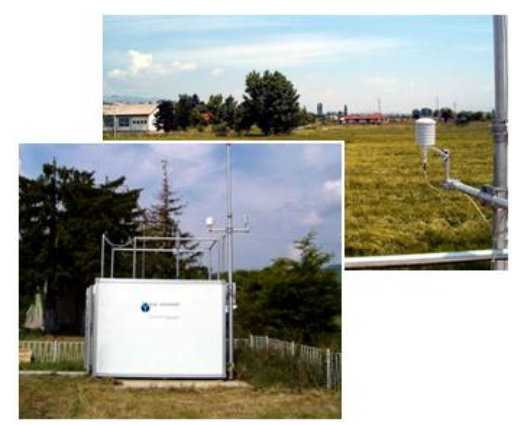

Figure 1. Monitoring station Bitola 1 Source: [6]

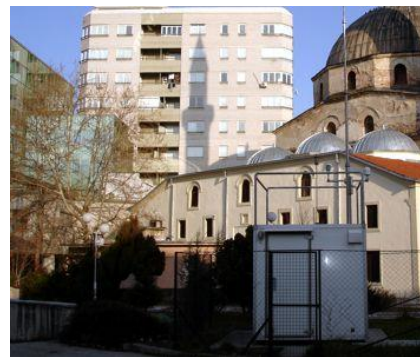

Figure 2. Monitoring station Bitola 2 Source: [6]
The usual obstacles for systematic monitoring of the pollutants, especially of the particles $\left(\mathrm{PM}_{10}\right.$ и $\left.\mathrm{PM}_{2,5}\right)$, and for the network creation are working/maintenance cost and cost for repair of the instruments, as well as the shortage of qualified personnel.

Without monitoring network to cover the whole urban centre and surrounding residential and rural areas, it is obscure to have real-time information for the level of air pollution. Moreover, no modeling of industrial, transport and household pollution is undertaken to predict future pollutants concentrations or risks from air pollution.

\subsection{Results of the monitoring measurements}

According to the Annual report of environmental quality data (the latest one for 2018), measurement of particles (which are the biggest problems for air quality) at Bitola 1and Bitola 2 continuously exceed air quality standards for $\mathrm{PM}_{10}[4]$.

According to the report, the average annual concentration at both stations is around $50 \mathrm{mg} / \mathrm{m}^{3}$, with annual limit value being $40 \mathrm{mg} / \mathrm{m}^{3}$. The problem is additionally emphasized by the following: if permitted excedance is 50 days/year, two stations shows up to 92 days/year with excedances of daily limit value [4].

For $\mathrm{PM}_{2}$ the situation is similarly serious: the annual average concentrations at Bitola 2 are above the maximal level of $26 \mathrm{mg} / \mathrm{m}^{3}$, being around $33 \mathrm{mg} / \mathrm{m}^{3}$ [4]. At this station it should be considered that for measured amounts of particles, apart of industry, the main contributors are urban transport and households.

Other pollutants measured are in the limited values and don't represent problem for air quality [4].

Hence, the revolt from the public is clear and justified on the basis on data from two monitoring station it can be concluded that the pollution in the town has deteriorated air quality. Therefore, the public is determined in its quest for starting point as a way out of this non-qualitative life.

\subsection{Public reactions}

In those urban areas where monitoring network is established, the link between data from monitoring sensors and end-users should function as shown in Fig. 3. But, in the town of Bitola, this link is missing. This has been an initial trigger for public revolt and protests. 


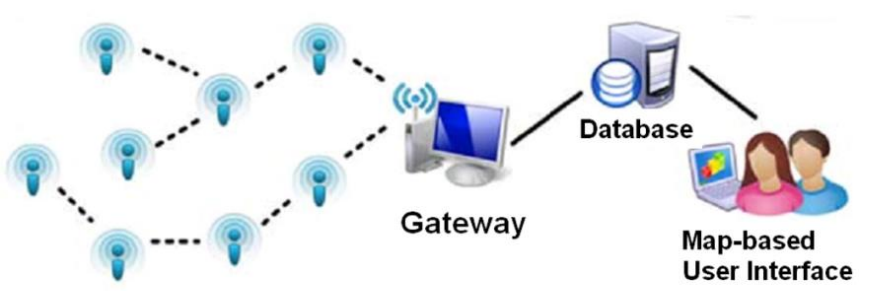

Front-end: geo-sensor network (monitoring area)

Figure 3. Monitoring network in function Source: [7]

Air pollution problem, especially intensive during the winter (Bitola often has temperature inversions, which last for couple of weeks), often not publicly and explicitly reported, has initiated displeasure of public. Their rage towards inactivity of authorities to deal with air pollution problem was manifested through several protests (held on 04.11.2014 and 13.12.2014).

The paroles of the protests were deeply significant: "We want to breed", "Take off the gas-masks", "Air is a life, air is a right", "Bitola on gills" (Fig. 4). Several demands had been delivered from NGO "It's all about us" to local authorities: urgent placement of monitoring system in central area of the town; air pollution reduction and system of penalties for biggest air polluters; maintenance of air quality according to permissible limits.

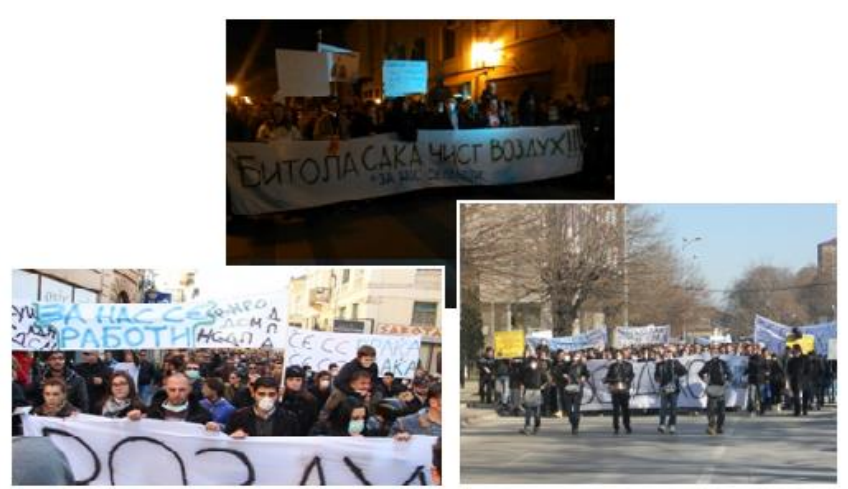

Figure 4. The atmosphere of the public protests Source: [social media]

So far, public reaction achieved no progress in their quest and situation is unchanged. Therefore, public protests are not longer at the streets, but are transformed into campaigns for public awareness, without wide media cover and support. Unfortunately, still without any visible results from local authorities to start with any kind of activity.

\section{THE RELEVANCE OF MONITORING IN THE SYSTEM FOR AIR QUALITY MANAGEMENT}

Air Quality Management System (AQMS) is directed towards designing and implementing control strategies, assessing their results, determining the consequences for air quality and measuring progress [8].
AQMS includes a number of closely related tasks that can be grouped into monitoring, modeling and data presentation using GIS, together with related reporting and public information. Hence, it enables the user not only to present and evaluate the current situation, but also to undertake environmental planning for sustainable future (Fig. 5).

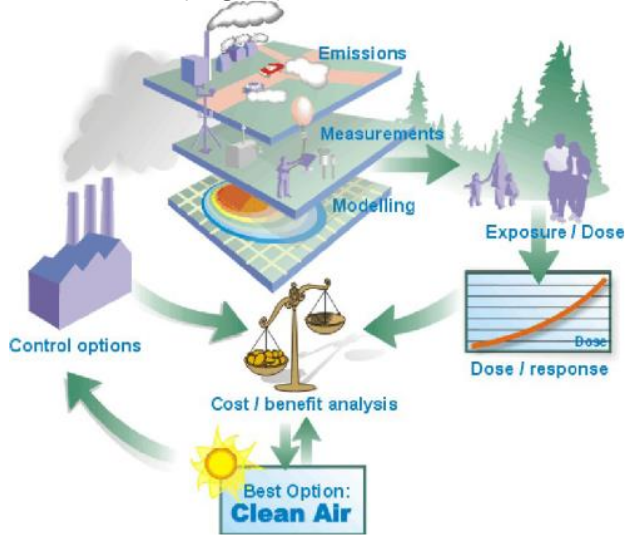

Figure 5. Elements of an optimal abatement strategy planning system Source: [9]

In the frame of AQMS monitoring should be integrated with air quality modeling and GIS. All these features are designed to address difficult analytical problems with large volumes of data, and at the same time provide a convenient and easy to use user interface [3].

In AQMS, monitoring is the first operation. Continuous monitoring data have many uses throughout the process of air quality management, such as [8]:

\footnotetext{
- determining compliance with air quality standards;

characterizing air quality and trends;

estimating health risks and ecosystem impacts;

- developing and evaluating emission control strategies;

evaluating source-receptor relationships;

- providing data for input to run and evaluate models; and

measuring overall progress of air pollution control strategies.
}

The data also form the basis for air quality forecasting and other public air quality reports. Hence, monitoring is needed to keep authorities, major polluters and the public informed on the short- and long-term changes in air quality, thereby to help in raising awareness [8].

At present, AQMS are applied in many cities in the world, considering them as an opportunity for improvement of air quality planning. 


\section{RECOMMENDATIONS FOR BUILDING OF MONITORING NETWORK}

Monitoring air for pollutants is a complex technical task, requiring not only direct measurement, but also measurement standards and quality assurance to ensure that the information provides a correct understanding.

The key recommendations for Bitola town are [8]:

New urban monitoring network need to be built on the current monitoring stations, but also to incorporate new directions in monitoring and to begin filling measurement and technological gaps that have accumulated over the years.

Monitoring network need to produce high quality data by:

- including a higher number of multipollutant monitoring sites in urban, but also in surrounding rural areas; monitoring sites should comprise stationary and mobile stations, with an option to work either independently or in direct connection with a central station through wireless technology [1];

- expanding use of advanced, continuously operating instruments and new information transfer technologies;

- supporting advanced research level stations.

- The importance of rural background monitoring for evaluating long range transport, cross-border concerns and long-term trends needs to be recognized [8].

A new urban monitoring network design should provide:

- data presentation through contour maps for air quality [2];

- trend determinations and seasonal variations;

- comparison with air quality standards;

- reporting to the public;

- assessment of the effectiveness of emission reduction strategies;

- assessment of source-receptor relationships:

- health assessments data;

- verification of the modeling results and assessment of the deviations.

Periodic assessments of monitoring network must be performed to determine if the existing network structure is optimally meeting national and local objectives referring station representativeness and monitoring accuracy.

- The network modifications should be conducted within current resource allocations used to support monitoring (e.g., with respect to staffing). However, modest investments in new equipment are needed to upgrade monitoring systems in order to meet new priorities and accommodate advanced technologies.
- Public opinions and suggestions should be engaged in the network changes.

- Finally, for air quality monitoring is especially important to be regularly performed and institutionalized [2].

Reliability of monitoring is crucial. The real monitoring must be well documented. Today, low- as well as hightechnological monitoring methods are available, with their own advantages and disadvantages. Regardless of the choice, the technology must be appropriate in a sense of resource availability and maintenance [2].

\section{CONCLUSION}

Air pollution becomes a problem when ambient concentrations of harmful pollutants are increased and exposure is high. Episodes with high concentration levels of harmful pollutants have negative impacts on the health and environment. In order to minimize the effects from these episodes, it is necessary to be followed.

Monitoring is a first step in building a system for air quality management. Developing focused monitoring network will contribute for prioritization and clarification of the air pollution problem and latter for assessment of the improvements considering chosen and implemented strategies.

Monitoring is essential to assessing the effectiveness of air pollution control strategies and to keep authorities, major polluters and the public informed on the short- and long-term changes in air quality, thereby helping to raise awareness.

Having these important roles for air quality management, monitoring should be established in the Bitola town, in order to start dealing with the current air pollution problem. It is clear that the air pollution problem is real and serious and cannot be neglected. Expressed public revolt through years for unacceptability of air pollution problems has been an initial trigger that has a potential to make a difference. Hence, this paper emphasizes the significance of monitoring network and gives recommendations for its introduction.

In brief, with a focus on minimal maintenance and low cost of ownership, air quality monitoring network should be reliable, easy to use in the field for both long-term and short-term deployments, and to features research-level accuracy. Experience of the towns, long-term commitments, long-term financing and training are key factors for establishing successful monitoring network [2]. 


\section{Acknowledgements}

This paper was presented at the $7^{\text {th }}$ International conference "Towards a humane city", 6-7.12.2019, Novi Sad, Serbia.

\section{References}

[1] Advanticsys - ISO9001 certified company. Air quality monitoring solutions for industrial and urban environments. Available online: https://www.advanticsys.com/portfolio/airquality-monitoring/ (accessed on 25 September 2019).

[2] United Nations environment programme (2005). Urban air quality management toolbook, United Nations human settlements program, Nairobi, Kenya, p. 55.

[3] Sivertsen, B. (2001). Air quality management and abatement strategy planning, Norwegian Institute for Air Research NILU, Norway.

[4] Annual Report (2018). Quality of the environment in the Republic of North Macedonia, Ministry of environment and physical planning, Skopje, Macedonia, p. 123.

[5] Angelevska B., \& Markoski A. (2011). Calculation of urban transport emissions: a case study for the town of Bitola, Proceedings of the 31st Conference on transportation systems with international participation - Automation in transportation, KoREMA, Pula/Croatia-Milano/ltaly, November 15-20, 2011, pp.7-12.

[6] Ministry of environment and physical planning in $\mathrm{N}$. Macedonia. Web portal for air quality. Available online: http://airquality.moepp.gov.mk/?lang=en (accessed on 20 September 2019).

[7] Wen, T.J., Jiang, J.A., Sun, C.H., \& Juang, J.Y. (2013). Monitoring street-level spatial-temporal variations of carbon monoxide in urban settings using a wireless sensor network (WSN) framework, Int. J. Environ. Res. Public Health, 10(12), pp. 6380-6396.

[8] Strategic planning (2005). National Ambient Air Monitoring Strategy, Office of Air Quality Planning and Standards, Research Triangle Park, NC, USA, p. 125.

[9] Norwegian Institute for Air Research NILU. AirQUIS: A modern air quality management tool. Available online: https://www.nilu.no/en/?s=airquis (accessed on 10 October 2019). 